\title{
PRODUCTION OF URANIUM-MOLYBDENUM ALLOY AS A CANDIDATE FOR NUCLEAR RESEARCH REACTOR FUEL
}

\author{
Ganisa Kurniati Suryaman ${ }^{1,2}$, Muhammad Waziz Wildan ${ }^{2}$, \\ Supardjo ${ }^{1}$, Yatno Dwi Agus Susanto ${ }^{1}$
}

${ }^{1}$ Center for Nuclear Fuel Technology - National Nuclear Energy Agency of Indonesia

Kawasan Puspiptek Serpong Gd.20 Tangerang Selatan, Banten 15314

${ }^{2}$ Department of Mechanical and Industrial Engineering-Gadjah Mada University

Jalan Grafika No.2 Yogyakarta 55281

e-mail: ganisa@batan.go.id

(Naskah diterima: 20-10-2018, Naskah direvisi: 28-11-2018, Naskah disetujui: 12-12-2018)

\begin{abstract}
PRODUCTION OF URANIUM-MOLYBDENUM ALLOY AS A CANDIDATE FOR NUCLEAR RESEARCH REACTOR FUEL. Research and development on high density uranium for nuclear research reactor fuel is still in progress. Uranium-molybdenum alloy is one of the strongest candidates of nuclear research reactor fuel material. The properties and characteristics of U-Mo alloy is of important consideration for the selction of the fabrication techniques for the production of the fuel. In this work, uranium-molybdenum (U-Mo) alloys with varied molybdenum content have been produced succesfully by arc melting technique. The molybdenum content variations were $7 \% w t, 8 \% w t, 9 \% w t$ and $10 \% w t$ Mo. The melting process was done 5 times to achieve homogenization. Metallographic micrograph shows the presence of dendritic structure. XRD examination result affirms the presence of 2 phases of $\mathrm{Y}-\mathrm{U}$ phase and $\delta-\mathrm{U}_{2}$ Mo phase. Microhardness Vickers test shows higher hardness value for Uranium-molybdenum alloy with higher molybdenum content.
\end{abstract}

Keywords: U-Mo alloy, research reactor, fuel. 


\section{ABSTRAK}

PEMBUATAN PADUAN URANIUM-MOLYBDENUM SEBAGAI KANDIDAT BAHAN BAKAR

REAKTOR RISET. Pengembangan bahan bakar reaktor riset untuk mendapatkan bahan bakar densitas uranium tinggi dengan pengkayaan rendah $\left(<20 \%{ }^{235} \mathrm{U}\right)$ masih terus dilakukan. Salah satu kandidat material bahan bakar reaktor riset adalah paduan U-Mo. Sifat dan karakteristik paduan U-Mo sangat berpengaruh terhadap pemilihan proses fabrikasi dan parameter pembuatan bahan bakar reaktor riset. Selain itu, kualitas paduan yang dihasilkan akan mempengaruhi unjuk kerja material bahan bakar ketika digunakan di reaktor. Pembuatan paduan U-Mo dengan variasi kadar Mo sebesar 7, 8, 9, dan 10 \%berat Mo telah berhasil dilakukan dengan peleburan menggunakan tungku busur listrik dalam media gas argon. Masing-masing paduan dilebur sebanyak $5 x$ sehingga diperoleh paduan yang homogen. Hasil karakterisasi paduan U-Mo menggunakan mikroskop optik menunjukkan terdapat struktur dendritik pada ingot paduan U-Mo. Hasil XRD memperlihatkan bahwa fasa yang terbentuk pada paduan U-Mo adalah fasa gamma $U$ dan fasa $\delta-U_{2}$ Mo. Hasil pengujian kekerasan mengunakan micro Vickers menunjukkan bahwa terjadi peningkatan kekerasan paduan seiring dengan meningkatnya konsentrasi molybdenum.

Kata Kunci: Paduan U-Mo, reaktor riset, bahan bakar. 


\section{INTRODUCTION}

At the beginning of research reactor operation, high-density uranium (enrichment $>20 \%{ }^{235} \mathrm{U}$ ) was used for its fuel. High-density uranium is very prone to proliferation. In 1978, The Reduce Enrich Research and Test Reactor (RERTR) program was implemented to develop the technology necessary to enable the conversion of civilian facilities using High Enriched Uranium (HEU) to Low Enriched Uranium (LEU) fuels and targets [1]. Because of this program, many researchers and engineers in nuclear research reactor fuel field are focusing on making a high-density fuel to keep the research reactor performance as high as when using HEU despite using LEU fuel. The promising candidates for nuclear research reactor fuel material are pure uranium metal, metallic uranium alloy and also high-density intermetallic uranium compounds [2].

Pure uranium metal has 3 allotropes viz; Orthorombic $\alpha-U$ (stable up to $662{ }^{\circ} \mathrm{C}$ ), tetragonal $\mathrm{B}-\mathrm{U}$ (stable from $662-769{ }^{\circ} \mathrm{C}$ ) and body center cubic $\mathrm{Y}-\mathrm{U}$ (stable from 769-1130 ${ }^{\circ} \mathrm{C}$ ) [3]. Pure uranium metal naturally has alpha uranium structure. Alpha uranium phase has low corrosion resistance and poor irradiation behavior in the terms of thermal and irradiational growth during reactor operating condition [4]. These conditions make pure uranium with alpha phase unsuitable as nuclear research reactor fuel. On the other hand, isotropic $y$ uranium phase has good irradiation behavior. It is very stable at low burn up and thermal irradiation growth under power ramping [2]. In pure uranium, the $Y$ phase exists in high temperature and it cannot be retained in a metastable condition at low temperature. Pure uranium metal has to be alloyed in order to retained the metastable $y$ phase. Metals which could be used as an alloying element for uranium such as $\mathrm{Nb}$, $\mathrm{Ru}, \mathrm{Ti}, \mathrm{Mo}, \mathrm{Cr}, \mathrm{Re}$. Molybdenum relatively has higher range of solute concentration to form $\mathrm{Y}$-phase if alloyed with uranium metal. Molybdenum also has lower neutron capture cross section compared to other alloying elements that has been mention before [4]. The stability of $y$ phase increases with the increase of molybdenum content in the uranium-molybdenum alloy. For usage as nuclear research reactor fuel, the maximum molybdenum content in U-Mo alloy is set at $10 \% w t$, thus the maximum uranium density in the fuel plate could be met [2].

Alloy preparation is one of the most important steps in making the uranium alloy as a nuclear research reactor fuel. There are many methods that could be used to make uranium alloy. Some researchers use induction method while some other use arc furnace or powder metallurgy to prepare uranium-molybdenum alloy. Sinha et.al used powder metallurgy to make uranium-molybdenum alloy [4]. Sinha et al concluded that in powder metallurgy process, mixing stage should get extreme care because this stage determines the homogeneity of final product alloy. Oliveira et al sucessfully fabricate uranium molybdenum alloy through induction and arc furnace method [5]. It is observed that each method has its own advantages and challenges. Researches about alloy preparation with different variations such as alloy composition and alloy heat treatment variations are still developing.

The present work focuses on uranium-molybdenum alloy production with Mo content variation using arc furnace technique. Understanding the structure and properties of uranium-molybdenum alloy is very important in determining fabrication process parameter. The uranium alloy quality will affect nuclear fuel performance. Alloy characterization was conducted mainly in term of optical microscopy and X-ray diffraction. The mechanical property observed is the hardness of the alloy. 


\section{METHODOLOGY}

Depleted uranium with $98.87 \%$ purity was used as raw material. U-7wt.\%Mo, U-8wt.\%Mo, U-9wt.\%Mo, $\mathrm{U}-10 \mathrm{wt}$ \%Mo alloy (here after called U-7Mo, $\mathrm{U}-8 \mathrm{Mo}, \mathrm{U}-9 \mathrm{Mo}, \mathrm{U}-10 \mathrm{Mo}$ ) were prepared by using arc melting furnace. The output current in the melting process was $150 \mathrm{~A}$. The samples were melted and turned over 5 times to accomplish homogenization. The melting process was done in argon atmosphere.

For metallographic examination, all samples were mounted, ground, polished and etched before being examined by optical microscope (Nicon Ephipot). The metallographic picture of every alloy was taken in two positions which are at the center and edge of the alloy ingot.

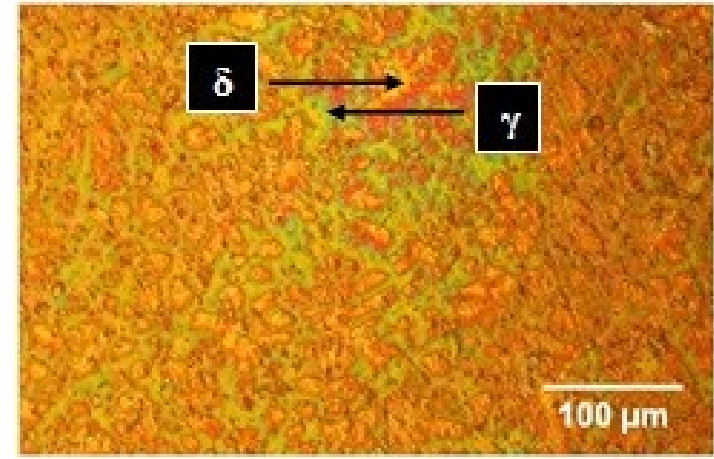

(a)

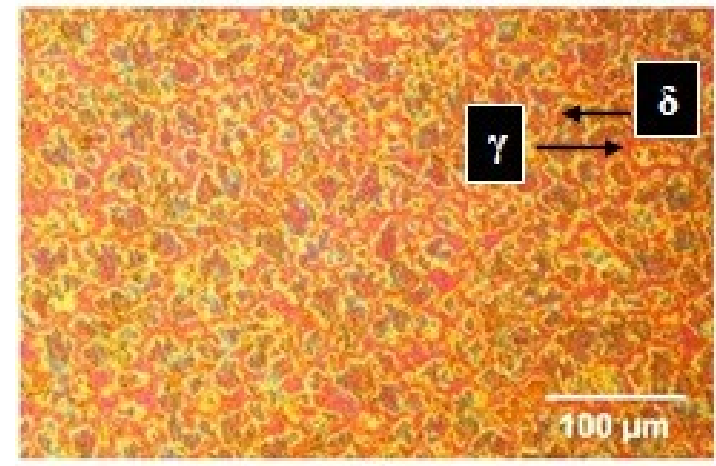

(c)
The sample phase compositions were analyzed using $X$-ray diffractometer (PANALYTICAL-Empyrean). The angle $2 \theta$ scanning range for examination was $20^{\circ}-80^{\circ}$ and the step size was 0.02 and the radiation source was $\mathrm{Cu} \mathrm{Ka}$. The tube was operated at $40 \mathrm{kV}$ and the current was $30 \mathrm{~mA}$.

The hardness test of U-Mo alloy with different molybdenum content was carried out using Micro Vickers hardness tester. The tool was Leitz Miniload.

\section{RESULTS AND DISCUSSION}

The metallographic picture of $\mathrm{U}-\mathrm{Mo}$ alloy with different molybdenum content in edge position of the U-Mo alloy ingot can been seen in figure 1. It can be seen that the sample has similar microstructure in edge position.

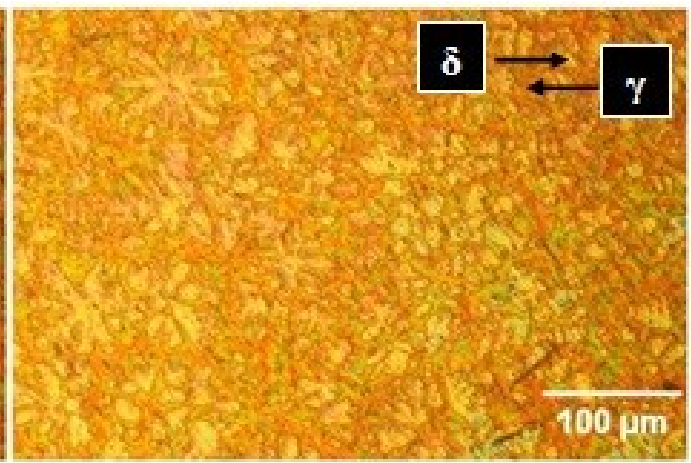

(b)

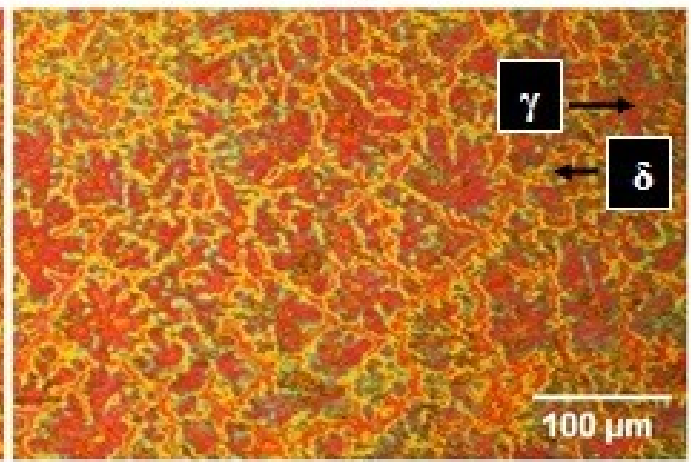

(d)

Figure 1. Metallographic photos in edge position. (a) $U-7 M o$, (b) $U-8 M o$, (c) $U-9 M o$, (d) $U-10$ Mo 


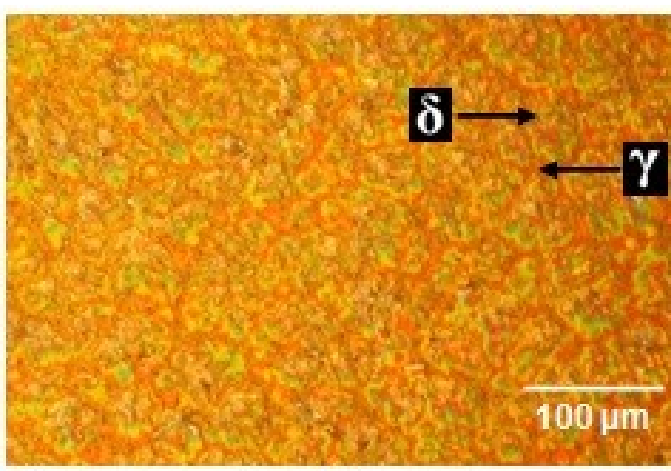

(a)

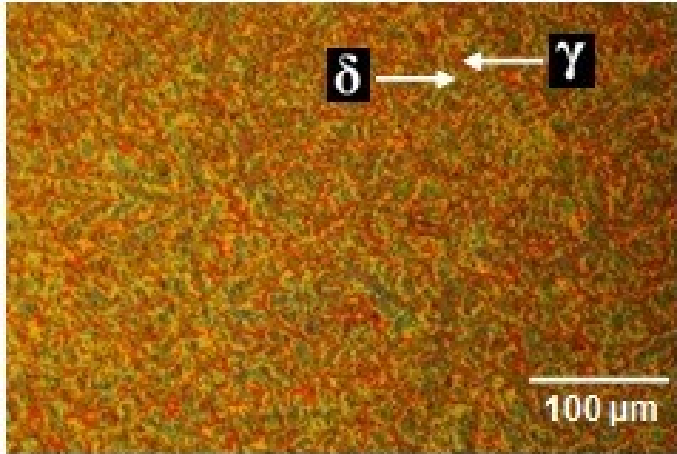

(c)

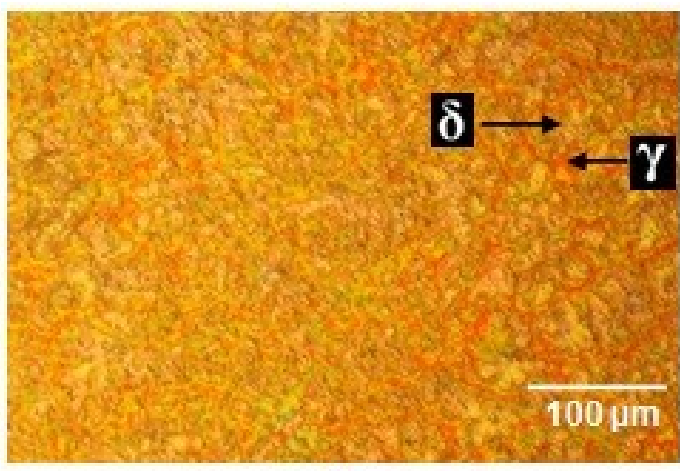

(b)

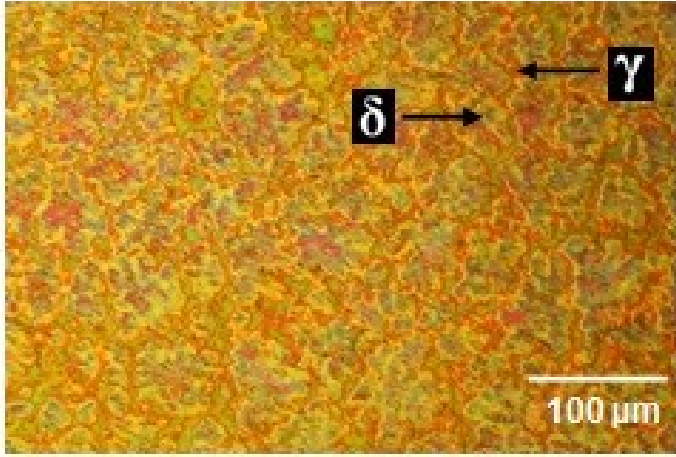

(d)

Figure 2. Metallographic photos in center position,(a) U-7Mo,(b) U-8Mo,(c) U-9Mo,(d) U-10 Mo.

Most of the alloy has relatively small grain size around $30-40 \mu \mathrm{m}$. This may be due to rapid cooling in melting process. During the melting process, the edge position is the first part of the alloy that interact with melting chamber which connected to cooling water. Because of this interaction, the cooling rate at the edge position will be faster than at the center position of the alloy. It makes the nucleation of the grain to be faster than the grain growth. This phenomenon makes the grain size at the edge position smaller than at the center position.

Figure 2 shows the microstructure of uranum-molybdenum alloy at the center position. It can be seen that the grain size at the center position is slightly bigger than the grain size at the edge position. Slower cooling rate allows grain to grow, therefore the grain size in the center position is bigger than the grain at the edge position of the alloy ingot.

Figure 1 and 2 also show some dendritic microstructure. The same microstructure photograph is found in uranium-molybdenum alloy made by Supardjo et al and Oliveira et al using arc melting technique[6,7]. Although the sample had been turned over 5 times during melting using arc melting technique, the dendritic structure is still present. Dendritic structure indicates difficulties in homogenization process in arc melting technique [7]. 


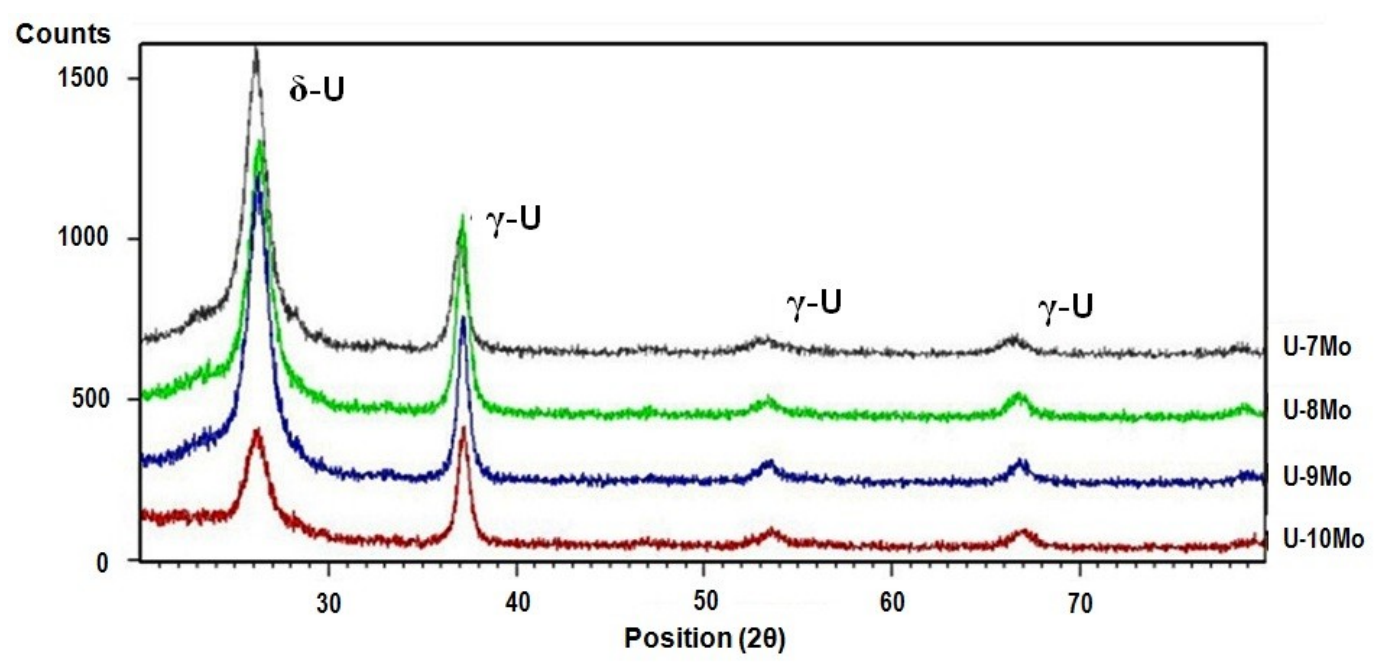

Figure 3. XRD pattern of U-Mo alloy with molybdenum content variation.

Figure 3 shows the XRD pattern of U-Mo alloy. It can be seen that the four samples have similar pattern. Two phases are present: gamma phase and $\delta-\mathrm{U}_{2} \mathrm{Mo}$ phase. The uranium is alloyed with molybdenum to stabilize the gamma phase at room temperature [8]. The metastable cubic gamma phase of U-Mo alloy could be retained under $560^{\circ} \mathrm{C}$ either by rapid cooling from gamma phase field or by adding sufficient quantities of molybdenum in the alloy [9]. The gamma phase is present in all the samples. It means that it is possible to produce gamma phase U-Mo alloy using arc melting process with Mo content range from $7 \%$ wt Mo - $10 \%$ Mo. The $\delta-U_{2}$ Mo presence in U-Mo alloy from arc melting process is also reported by Oliveira et al. The $\delta-U_{2}$ Mo peak appearance in the XRD result indicates some inhomogeneity trough eutectoid phase [7].

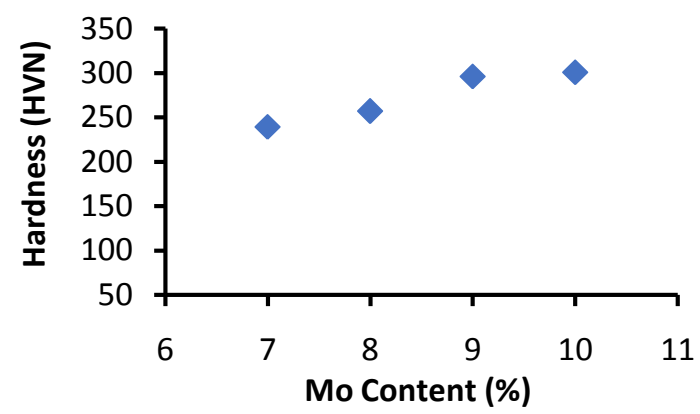

Figure 4. U-Mo alloy hardness with molybdenum content variation.
Figure 4 shows the hardness of uranium molybdenum with variations of molybdenum content. It can be incurred that the higher the molybdenum content, the higher the hardness of the alloy. The same result is also reported by Burkes et al [10]. Solid solution strengthening is believed to be the reason behind this phenomenon. Molybdenum goes into solid solution with uranium. Molybdenum as impurity atom imposes lattice strain on sorrounding house atom, in this case uranium is the host atom. The interaction between the lattice strain, impurity atoms and dislocation results in restriction of dislocation movement. The more impurity atoms in the alloy, the more lattice strain is formed. Thus, dislocation movement will be more restricted. This phenomenon influenced materials to become harder.

\section{CONCLUSION}

The U-Mo alloy with variation of Mo content has succsefully been produced using arc melting technique. From optical identification it can be observed that dendritic structure is present in the U-Mo alloy. Phase identification showed there are two phases exist in the alloy, the gamma uranium and $\delta-U_{2}$ Mo phase. It is also observed that the hardness increase with the increase of molybdenum content. 


\section{ACKNOWLEDGEMENT}

We thank the head of PTBBN BATAN and all staff especially in Experimental Fuel Element Installation for their support.

\section{REFERENCE}

[1]. E. E. Pasqualini, "Gamma Uranium Molybdenum Alloy: its Hydride and Performance," in Nuclear Material Performance, IntechOpen, 2016.

[2]. S. Neogy, M. Saify, S. Jha, D. Srivastava, M. Hussain, G. Dey and R. Singh, "Microstructural study of gamma phase stability in U-9 wt.\% Mo alloy," Journal of Nuclear Material, vol. 422, no. 1-3, pp. 77-85, 2012.

[3]. V. Yemelvanov and A. Yevstyukhin, The Metallurgy of Nuclear Fuel Properties and Principles of the Technology of Uranium, Thorium and Plutonium, London: Pergamon Press Ltd., 1969.

[4]. V. Sinha, G. Prasad, P. Hedge, R. Keswani, C. Basak, S. Pal and G. Mishra, "Development, Preparation and Characterization of Uranium Molybdenum Alloys for Dispersion Fuel Application," Journal of Alloys and Compounds, vol. 473, no. 1-2, pp. 238-244, 2009.

[5]. F. Oliveira, M. Durazzo, H. Riella, "Methods for Fabricating gamma-uranium-molybdenum alloys and their influence on powder obtention by the $\mathrm{HDH}$ technique,"
Nuclear Fuel Center, Nuclear and Energy Research Institute-IPEN, 5 October 2015.

[6]. Supardjo and Masrukan, "Production and Charachterization of UMo alloy as Candidate of Nuclear Fuel Dispersion Type," Jurnal Teknologi Bahan Nuklir, vol. 4, pp. 48-57, June 2008.

[7]. F. B. V. d. Oliveira, E. F. U. d. Carvalho and H. G. Riella, "Fabrication Results of Gamma Uranium-Molybdenum Alloys Fuels," in International Nuclear Atlantic Conference, Rio de Janeiro, 2009.

[8]. A. Clarke, K. Clarke, R. McCabe, C.T.Necker, P.A.Papin, R. Field, A. Kelly, T. Tucker, R. Forsyth, P. Dickerson, J. Foley, H.Swenson, J. R.M. Aikin and D. Dombrowski, "Microstructural evolution of a uranium-10 wt.\% molybdenum alloy for nuclear reactor fuels," Journal of Nuclear Materials, vol. 465, pp. 784-792, 2015.

[9]. V. P. Sinha, "Studies on the Preparation and Charachterization of U3Si2 Intermetallic and U-Mo alloys," Ph.D. dissertation, Homi Bhabha National Institute, Mumbay, Maharashtra, India, 2012.

[10]. D. E. Burkes, R. Prabhakaran, J.-F. Jue and $\mathrm{m}$. J. Rice, "Mechanical Properties of DU-xMo Alloys with $\mathrm{x}$ =7-12 Weigjt Percent," Metallurgical and Materials Transactions $A$, vol. 40A, pp. 1069-1079, 2009. 
Vol. 24 No. 3, Oktober 2018: 135-198

p ISSN 0852-4777; e ISSN 2528-0473 